\title{
LABOR AND THE THEORY OF THE MEXICAN REVOLUTION UNDER LÁZARO CÁRDENAS
}

\section{Introduction and Purpose}

QINCE Mexico now seems to be the key nation in Latin America $D$ in the implementation of President Kennedy's Alliance for Progress, it becomes even more pressing that we in the United States understand the nature of the Mexican social order. As a point of departure for this effort, one might well begin by considering the basis for contemporary industrial and political development of Mexico as formulated in the years 1934-1940 under Mexico's New Deal of Lázaro Cárdenas. Sanford Mosk noted, ". . . what went on during the time of Cárdenas has had an indirect effect on the subsequent industrial development." 1 Or, as the United States Tariff Commission claimed, the reorientation of Mexico's economic and social policy has been an important part of her political life since $1910 .^{2}$ The new program was given impetus by the Constitution of 1917, which contained important provisions for agrarian reform and for the protection of labor. Yet, aggressive implementation of the new policy began under president Lázaro Cárdenas with the inauguration of the Six-Year Plan in 1934.

While the topic of Mexican agrarian reform during this vital formative period has been the subject of considerable study, there is a notable paucity of information in English concerning the development of labor theory and policy. The purpose of this paper is to make a beginning inquiry into the role of labor in national statecraft as viewed by Cárdenas and his associates. If it is true that "With the inauguration of Lázaro Cárdenas as president of the country began an epoch never before equaled in importance in the public life of Mexico-in all aspects, economic and social, ${ }^{3}$ then perhaps an inquiry into the general socioeconomic philosophy of the revolutionary government of Cárdenas, with special reference to labor theory, will prove worthwhile.

Such an approach to the understanding of what has been generally

${ }^{1}$ Sanford A. Mosk, Industrial Revolution in Mexico (Berkeley, 1950), p. 59.

2 United States Tariff Commission, Economic Controls and Commercial Policy in Mexico (Washington, D. C., 1946), p. 17.

${ }^{3}$ Alfonso López Aparicio, El movimiento obrero en México: antecedentes, desarrollo $y$ tendéncias (México, 1952), p. 213. 
termed "the Mexican Revolution" would seem particularly valid in view of the fact that Cárdenas himself, in the early part of his term, upon reminding the public that he had once been a laborer in a small shop, remarked, "Being loyal to my class, the class that elevated me to the presidency, my program of government seeks by legal means the emancipation of the masses of day laborers and peasants." 4 This statement contained a key to two aspects of the labor theory of the administration-the recognition of the existence of a proletarian class, and the use of government action as a legitimate technique for aiding the working class.

The question becomes: by what method, and for what end, did Cárdenas and his more articulate followers propose to give the workers an opportunity to become full members of our civilization? What was the labor philosophy of this epoch as expressed in what Cárdenas considered the basic documents of the Revolution-the Constitution of 1917, the first Six-Year Plan, the Federal Labor Law of 1931, the declarations of the Partido Revolucionario Nacional (P.N. R.) and the Partido de la Revolución Mexicana (P. R. M.), the Confederación Trabajadores de México (C. T. M.) and the Confederación Trabajadores de América Latina (C. T. A. L.), the speeches and writings of Cárdenas and his economic advisors, Lombardo Toledano, and the Department of Labor? Is there any unity in the thought? What similarities and what differences, if any, did the Mexican labor theory of this era have with labor theories of other countries? In short, what was the nature of the thinking of the Mexican Government towards the organization of the working class of Mexico during the period 1934 through 1940?

\section{II}

\section{General Socio-Economic Theory of the Revolution}

While an analysis of labor theory is the final object, the approach in this paper shall be to examine the general philosophy of the Revolution as interpreted by Cárdenas with regard to the new era in its political, social, and economic aspects, with emphasis on his theory of labor in the Mexican environment. It is felt that only in this manner can a more genuine understanding of the place of organized labor in the national economy of the nation be obtained. In one of his more idealistic utterances the President claimed:

\footnotetext{
${ }^{4}$ From a speech to the peasants at a town in the State of Guanajuato, March 31, 1936, as quoted in William Cameron Townsend, Lázaro Cárdenas: Mexican Democrat (Ann Arbor, 1952), pp. 56-57.
} 
The aspiration of the revolution is that every man in every village shall find work, so that human life may be pleasanter, less miserable and nobler in this sense, in that it shall allow the individual to cultivate his physical and intellectual faculties, and therefore to achieve full realization of his own personality. ${ }^{5}$

Apparently, then, a primary general goal of the reform program of this era was full employment. As evidence of the aim toward achieving a better distribution of wealth, as well as political and economic democracy, it is pertinent to notice that Cárdenas held that the foundation of democracy rested upon a better distribution of wealth, the general raising of living standards, an equality of opportunity with regard to culture, and an equal chance for the working people to attain power. ${ }^{\mathbf{B}}$

According to one of the outstanding historians of the period, the Mexican Revolution stressed tendencies towards nationalism, Indianism, and agrarian reform, with extraordinary importance on the labor problem. Teja Zabre pointed out that among the mandates of the Constitution of 1917, Article 27, which dealt with agrarian problems, and Article 123, which was the basis of the whole of labor legislation, were looked upon as the most essential. ${ }^{7}$ He saw in the Revolution the following points aiming progressively at actual consummation: (1) to pass from theoretically equal rights, or equality on paper, to actual, that is, economic equality; and (2) in the field of labor to begin with unionism, so as later to achieve socialization. ${ }^{8}$ As we shall note at a later point the exact meaning of the term socialization may have been used in a somewhat peculiar sense; but for Teja Zabre it was Marxian in nature, since he noted:

I. Civilization and culture are the result of the work of man to bring Nature under control.

II. Labor is the fundamental cause and the closest measure of the value of useful things.

III. The structure of society is based on the organization of labor, that is, the technique of production.

IV. The main historical factor is class war. . . .

V. Direct action in this struggle is aimed at all wealth withdrawn from circulation by concentration and absorption, such as property

5 Policies of the Present Administration of Mexico (Mexico, 1936), p. 11.

${ }^{6}$ Townsend, Lázaro Cárdenas, p. 212.

${ }^{7}$ Alfonso Teja Zabre, Guide to the History of Mexico: A Modern Interpretation (Mexico, 1935), p. 347.

8 lbid., pp. 347-348. 
in mortmain held by religious corporations, owners of great estates, and exploiting capitalism. ${ }^{8}$

This interpreter felt further that it was necessary to take into account the need for nationalism and the alignment of classes, and once this latter had been accomplished the fundamental points of the Revolution would become the "insurgency of the proletarian classes seeking economic and actual equality," and the "creation of a new State to realize progressive socialization of the means of production." 10 In an analysis which may shed some light on what appears to be a special use of the term socialization, mentioned above, Teja Zabre said: ${ }^{11}$

The formula of the Mexican Revolution is intervention of the State in ęconomic production as an element of control, supervision, and balance, and the formation of the government with participation of all the social classes in a functional, democratic system, or, that is, organization of all the sectors of production. (Italics mine.)

The Mexican revolutionary system recognizes private property, but with limitations for the public interest and considers it as a social function. It tries to develop small property, small industries, commercial property of indigenous agrarians, and the cooperative forms of production and consumption, and the use of credit and technology in agriculture.

As can be seen from this latter description of the formula for the Mexican Revolution allowance is made for "some private property," and the actual encouragement of "small private industries," as well as the participation of "all the social classes in a functional democratic system "-apparently a sort of popular front, benevolent state attitude, with overtones of the corporate state of Italy of the 1930's. A major difference, however, seems to have been that organized labor was to have a primary role in the Mexican scheme. Nonetheless, the participation of all the social classes in government and the allowance of private productive property certainly puts certain qualifications upon the " insurgency of the proletarian classes seeking economic and actual equality," and the "creation of a new State to realize progressive socialization of the means of production." Apparently, socialization as used here, means neither more nor less than government intervention in or regulation of privately-owned productive property for the good

\footnotetext{
9 Ibid., pp. 354-355.

10 Ibid., pp. 355-356.

${ }^{11}$ Teja Zabre, "El Marxismo en la Revolución Mexicana: esbozo de una interpretación histórica," Futuro, III (Enero 1935), 1-14.
} 
of all the classes in a private-ownership society. It will be recognized that this concept of socialization is not the "orthodox" Marxian use of the term, which usually denotes public or collective orwnership of productive property-not merely state control and regulation of it. This special note, it seems to me, is necessary in order to avoid incorrect conclusions concerning the socio-economic philosophy of the Mexican Revolution under Cárdenas.

In answering charges that he was leagued with Soviet Russia, Cárdenas stated in comparatively precise terms his politico-economic philosophy when he denied the charge and explained:

Our government . . . is democratic and liberal, with a few moderate traces of socialism which affect land ownership, principally for restitution, and in the laws which refer to the relationship between capital and labor, but which are not nearly so radical as those of other democratic countries, or even of others which are monarchies.

... Our revolutionary movement was born of the hopes and needs of our country. It is not proper to attribute to it any similarity with existing social movements in other parts of the world, except those whose principles are common to any movement seeking proletarian justice and the cultural and economic improvement of the oppressed. ${ }^{12}$

Upon another occasion the President made clear his position with regard to Communism as follows:

We reject Communism because the adoption of a system which would deprive our people of the full enjoyment of the fruit of their labors is not in keeping with their temperament, nor do we desire that the old system of capitalistic overlords be substituted by an overlordship of the State. ${ }^{13}$

Especially interesting is Cárdenas' statement that he did not desire an " overlordship of the State," which in fact was the exact system which he suggested in the major portions of his writings and speeches, as shall be observed in the course of this inquiry.

Concerning any possible connection between Cárdenas and Soviet Communism, Strode felt that Cárdenas further disproved such a possibility when he admitted to Mexico in 1937 Stalin's arch-enemy, the exiled Leon Trotsky, and absolutely refused to recognize the government of the U.S.S. R. ${ }^{14}$ The General Secretary of the Communist

\footnotetext{
${ }^{12}$ From a speech by Cárdenas quoted in Hudson Strode, Timeless Mexico (New York, 1944), p. 354.

13 From a speech by Cárdenas quoted in Townsend, Lázaro Cárdenas, p. 212.

14 Strode, Timeless Mexico, p. 354.
} 
Party of Mexico, Hernán Laborde, in commenting upon a speech by Cárdenas noted that the President's pronunciations put him on the side of labor, but added:

The Communist Party does not accept blindly the entire program of the Cárdenas government. We realize, all too well, its faults and indecisions. Yet, at the same time, we realize also the necessity of supporting, with the aid of a strong united front, a progressive government such as that of Cárdenas when it is menaced by Fascism. ${ }^{15}$

This same line of reasoning was adhered to also by the labor leader, Vicente Lombardo Toledano, as shall be discussed in some detail later in this paper.

If the direction of the Mexican Revolution under Cárdenas cannot be explained in terms of a trend towards Soviet Communist orientation, what was Cárdenas' socio-political theory? What was the economic theory of his administration? He wanted to revamp the old P. N. R., which he had controlled since 1935. He desired a new machine free from the old abuses and as democratic as Mexico's background would permit. Therefore he decided to organize a federated party composed of four equal sectors-military, labor, peasant, and popular. The popular sector was to include all who were not aligned with one of the other sectors and it was to be the voice of the middle class, which Cárdenas hoped would be weaned from its friendship towards capitalism. The new party was to be as all-inclusive as possible, but would admit neither Communists nor the clergy. The P. N. R. went our of existence, and the Party of the Mexican Revolution (P. R. M.) was born on December $19,1937 .^{18}$

The declaration of principles and the program of action adopted by the P. R. M. declared that its most fundamental task was "the preparation of the people for the establishment of a workers' democracy as a step torward socialism." ${ }^{17}$ According to Genaro Vásquez, head of the Department of Labor:

The inclination felt by the chief of the State for the proletariat has made him, in pursuance of his convictions as to social matters, reinforce his party's plan and convert it into a program of government essentially

${ }^{15}$ From a speech by Hernán Laborde, quoted in Verna Carleton Millan, Mexico Reborn (Boston, 1939), p. 105.

${ }^{16}$ Townsend, Lázaro Cárdenas, pp. 216-217.

${ }_{17}$ P.R.M., Pacto constitutivo: declaración de principios, programa y estatutos (México, 1938); Nathaniel and Sylvia Weyl, The Reconquest of Mexico: The Years of Lázaro Cárdenas (New York, 1939), p. 347. 
constructive as regards the general economy of the nation and decidedly a protector of the working masses. ${ }^{18}$

Again it is imperative to remember that the "step toward socialism" which the Revolution under Cárdenas claimed to be taking, may have been used in some special sense, as mentioned previously, or even that it was used by different people at the same time to mean a different thing-or even used at different times by the same people to mean different things. The mere fact that the government party was pledged to be a "protector of the working masses" is not sufficient to warrant naming it as socialist party. The P. R. M. in its declaration of principles was not specific as to what it meant by a "workers' democracy," and " a step toward socialism." Strode noted that above all Cárdenas admired the social democracies of Scandanavia, but that he studied the needs of his people in relation to their temperaments and potentialities and Mexico's resources and mores, and he used common sense as well as humanitarian principles to motivate his reforms. ${ }^{10}$

The brilliant, young undersecretary of State for Cárdenas, U. S.-educated Ramón Beteta, in whom the President seemed to have unlimited confidence, at one time apparently agreed rather thoroughly with an orthodox interpretation of the statement of the P. R. M. mentioned above, with socialism understood to include the collective ownership of productive property, since he said:

We think that we should attempt to industrialize Mexico consciously, intelligently, avoiding the avoidable evils of industrialism, such as urbanism, exploitation of man by man, production for sale instead of production for satisfaction of human needs, economic insecurity, waste, shabby goods, and the mechanization of workmen. . . W We are convinced that the evils of capitalism are ... due to a merely legal question: who is the owner of the machinery? ${ }^{20}$ (Italics mine.)

Here it would seem that Beteta definitely inferred something other than private ownership of productive facilities. He amplified upon this explanation as he continued:

I believe that Mexico precisely because it finds itself in the pre-capitalist transition, is in a position favorable to the finding of a more humane and just system of economic relations by means of intelligent interven-

\footnotetext{
18 Genaro Vásquez in the Introduction to Policies of the Present Administration of Mexico (Mexico, 1936), p. 5.

${ }^{19}$ Strode, Timeless Mexico, p. 311.

${ }^{20}$ Ramón Beteta (ed.), Programa económico y social de México (una controversia) (México, 1935), p. 44; Clarence Senior, Mexico in Transition (New York, 1939), p. 48.
} 
tion of a government, with working-class interests. If it can avoid a fatal conflict with the capitalist imperialism of other countries which could, in one moment, put an end to the Mexican experiment and even to our very national existence, I believe that it will be able to evolve toward a society without classes which in our day is the condition nearest to the ideal in the economic relations of man. ${ }^{21}$ (Italics mine.)

This latter statement seems to be significant for our purposes for two reasons: first, the reference to the idea of government intervention in behalf of the working class; and second, because of the expression of a desire for a classless society. It is, of course, not clear whether the government with working-class interests is to be made up of members of the proletariat, some other exclusive group, or a popular front. Nonetheless, the reference to evolution towards a classless society, taken together with the question of who should own the productive machinery, have a good deal in common with "orthodox" Marxian socialism. Some further hint of the economic theory of Beteta may be gleaned from the following excerpt of a speech: "Some of us believe, furthermore, that profit-making is not the only incentive of human endeavor, but rather a motive that happens to have been chosen and over-developed in the capitalistic regime." ${ }^{22}$

When comparing the Six-Year Plan, as the statement of principle for the Cárdenas administration, with the Nerw Deal, Beteta revealed what he saw as a fundamental difference:

There is a similarity, it is true, between the New Deal . . . and the Mexican Six-Year Plan . . . as they both are efforts at harmony in planning the economic chaos produced by economic liberty. There are, however, fundamental differences between the American and the Mexican approach to the problem. Thus while the aim of the United States Government, as I understand it, is to increase the price by limiting production and making profits possible, we in Mexico are more concerned with the workers' side of the problem than with the industrialists'. We recognize the existence of the class struggle as one of the inevitable features of capitalism and we bave put our sympathy with the working class. ${ }^{23}$ (Italics mine.)

In the last two quotations we note the denial of the profit motive as the only incentive of human endeavor and the recognition of the class struggle as an inevitable feature of the capitalist system-both ideas Marxist.

\footnotetext{
21 lbid.

22 Quoted in Sanford A. Mosk, Industrial Revolution in Mexico, p. 58.

${ }^{23}$ Beteta, Programa económica y social de México, p. 95.
} 
What of the general socio-economic theory of another member of the Cárdenas team, that dynamic personality, Vicente Lombardo Toledano, to whom Millan referred as, ". . . the most unusual labor leader any country ever had. . . . Today (1939) he probably has more mass support than any other political personality throughout the Republic with the exception of Cárdenas himself; and I do not make this statement lightly." ${ }^{24}$ This writer maintained that as general secretary of the C. T.M. (Mexican Confederation of Labor) Lombardo was to play, with the coming years, a decisive role in Mexican politics and felt that, "He has the best all-around political intelligence in Mexico, and the dramatic impact of his speeches is due precisely to their irrefutable logic." ${ }^{25}$ Lombardo was appointed by José Vasconcelos, then Minister of Education, through the intervention of Antonio Caso, as director of the National Preparatory School. Vasconcelos and Lambardo had serious difficulties from the first-as did also Lombardo and his master, Castro, later. They split over the question of materialism. Lombardo had come to accept the historical materialism of Marx, and now talked openly of class struggle as the essential basis for all attempts toward a genuine unification of the working class. According to Millan, he differed with the Communists on matters of tactical rather than ideological nature. ${ }^{26}$ It should be noted, however, that his thought, along with that of other leaders of the C. T. M., was variable, capable of shifting as the Mexican environment changed in response to the world situation. In the words of López Aparicio, "Lombardo Toledano is the greatest intellectual leader of the Mexican labor movement-his ideological position has been mobile." ${ }^{27}$

From 1923 to 1931, while Lombardo was still in the C. R. O.M. (Regional Confederation of Mexican Workers) he had, according to Plenn, maintained a strict trade-unionist point of view, holding that the labor unions should function strictly as economic organizations for, defense of their rights against employers. Samuel Gompers could scarcely have agreed more, as indeed did Mexico's President Calles, who looked on the syndicalist trade unions as the bulwark of capitalism. Following the break with labor leader Morones in 1931, and before the formation of the Mexican Confederation of Workers (C. T.M.), Lombardo had been moving more towards a position in which he considered the role of the trade unions to be political as well as economic. ${ }^{28}$ (It is interest-

${ }^{24}$ Millan, Mexico Reborn, p. 81.

25 lbid.

26 Ibid., p. 87.

${ }^{27}$ López Aparicio, El movimiento obrero en México, p. 219.

${ }^{28}$ J. H. Plenn, Mexico Marches (New York, 1939), p. 265. 
ing to observe that the same change in view of labor toward political activity was to occur shortly afterward in the United States.) At the same time Lombardo's philosophy had veered from idealism and spiritualist theism towards the positivism and humanism of Auguste Comte, and then towards the dialectical, historical materialism of the Marxists. During this period the young scholar was expelled from the National University for "attempting to bring into it an alternative for the prevailing Bergsonian anti-scientific school and to open the way for the Marxist philosophy." He then founded the Gabino Barreda University, named for Mexico's outstanding proponent of Comte's positivism, with the idea of finding a compromise between idealism and materialism. This school was transformed in 1935 to a "Marxist" institution and its name changed to the Workers' University of Mexico. ${ }^{29}$ For some time liberal educators had looked upon the National University of Mexico as a nest of opposition to their "socialistic tendencies" and Cárdenas shared in this sentiment. ${ }^{30}$ With regard to this matter he observed while campaigning for the election:

The member of the laboring class who enters the halls of the university or technical schools does not usually become the leader who returns to take culture and help to his fellows, but rather, is the very one who turns his back upon them and goes over to the bourgeoisie. Under such conditions, each son of a working man who goes to schools of higher learning is lost as a potential leader to the syndicate or peasant organizations and becomes another expert at the service of the wealthy classes. By virtue of this phenomenon the cream of the proletariat come to be rich spoil for the purposes of the bourgeoisie. ${ }^{31}$

The Workers' University, an auxiliary of the C. T. M., endowed with the good will of Cárdenas, and supported partially by government funds, was converted into a center for the diffusion of the ideas of historical materialism. ${ }^{32}$

One of the earliest bulletins of the Workers' University set down the aims of the institution in this manner:

The most important task of this epoch of transition is to develop in the working class a consciousness of their historical mission. This is the purpose of the Workers' University. They must be shown their exact place in life and in the world, based on knowledge confirmed by

\footnotetext{
29 lbid.

30 Townsend, Lázaro Cárdenas, p. 124.

31 lbid., pp. 124-125.

${ }^{32}$ López Aparicio, El movimiento obrero en México, p. 220; Strode, Timeless Mexico, p. 321 .
} 
experience; in addition to concrete knowledge of the life of the country in which they live-its physical, economic, and social structure.

"Without a theory of revolution," said Lenin, "there can be no revolutionary action; but it must be seen that no revolutionary theory of the social struggle can exist if there is no scientific notion of the universe." It is for this purpose that the Workers' University comes to fill a grand purpose for the future of the proletariat. Workers will learn in these walls, in a systematic manner, the origin of the world, the origin of life, the appreciation of man, the principle of human society and its development, the material character of all natural phenomena, and the laws of dialectical materialism.

In possession of this fundamental knowledge of the true culture, the exploited will be able to go out with a firm conviction in their daily struggle against the capitalist class and have a clear vision of the future. ....3s

In short, the Workers' University claimed to be an institution dedicated to the study of socialist doctrine, of social problems in general, of the characteristics of the bourgeoisie rule, of the aspects of contemporary capitalism, of those countries without "automatic economics," and of the realities of social Mexico. ${ }^{34}$ It is interesting indeed to see at least a partial listing of the faculty of the school, which included the names of many of the leading intellectuals of the country. Besides the director, Vicente Lombardo Toledano, and the assistant director, Alejandro Carillo, there were Lic. Victor Manuel Villaseñor, Lic. Xavier Icaza, Federico Bach, Gonzalo Mora, Francisco Zamara, Alfonso Teja Zabre, Alfonso Millán, Juan O'Gorman, Antonio Ramírez Laguna, and Agustín Yáñez. $^{35}$

A dispute which arose in 1933 between Lombardo and his former professor, Antonio Caso, was the beginning of a polemic which has become one of the most famous in recent Mexican history. Caso called his pupil a renegade and an ingrate. Lombardo replied that he had been completely taken in by the idealist philosophy and had come to realize the untenability of that point of view. This debate, which raged for weeks in the newspapers, was sensational because it represented, according to Plenn, the fundamental division between the two main currents of thought in Mexico. ${ }^{36}$ During the debate Lombardo gave a summation of his philosophical position as follows:

\footnotetext{
${ }^{33}$ Universidad Obrera de México, 1936, pp. 4, 5, 6.

34 Ibid., p. 7.

${ }^{35}$ Ibid., pp. 2-3.

${ }^{36}$ Plenn, Mexico Marches, p. 266.
} 
... we believe that man is a product of nature; that the exterior world forms and guides his spirit; that his conscience is principally social and not individual; and that it is not man who makes bstory according to his will, but that bistory creates buman ideas, that liberty does not consist of separating man from nature, attributing divine power to him, but in proceeding rationally witbin the dialectical process of bistoric laws. ... ${ }^{87}$ (Italics mine.)

A further comment by Lombardo is of special interest because it demonstrates clearly that at one time his thought, like that of Ramón Beteta, was in harmony with "orthodox" socialism:

Socialization is reached only when private property disappears as the base and aim of social institutions, so that the collectivity, composed exclusively of workers, can impose on production and distribution the modalities necessary for society, without encountering any legal obstacles. So, as long as there is private property, there can be no socialized property. The two forms cannot exist side by side. . . .

Within the capitalistic regime the turning over of some centers of production to the workers does not necessarily lead to socialism. It is solely an act which may temporarily help the workers, to a greater or lesser degree, but the beneficiaries do not thereby free themselves of the consequences of the capitalist regime. ${ }^{38}$

It would seem quite clear that at this stage Lombardo stood for the public ownership of all productive property in the hands of a government composed exclusively of workers, and that any partial "socialization" of property could be of only temporary benefit to the workers, and should be indulged in merely as a matter of expediency. This interpretation seems to imply that Lombardo would not name the socio-economic system of Mexico under Cárdenas either socialist or communist, since private property did not disappear-nor did Cárdenas advocate such a situation; the collectivity was not composed exclusively of workers; and, as we shall note below, Lombardo himself stated that it should not be so composed. (At the same time, the role played by labor in the system probably precludes naming it Fascist.)

Concerning the position of organized labor with regard to the state, Lombardo declared in a floor debate at a labor convention in December, 1934:

It is not a question of incorporating workers' representatives into the state, but of recognizing the power of the working class organized

37 Vicente Lombardo Toledano, "Debate en pro," Futuro, II (Octubre, 1934), 50-63. ${ }^{38}$ Quoted in Plenn, Mexico Marches, p. 360. 
against the state. . . The root of this controversy is that comrades who oppose the motion uphold the anarchist ideology and believe that all power, merely because it is power, corrupts. I believe the opposite, for I believe that we must arrive at the dictatorship of the proletariat. ${ }^{39}$

This position was taken by Lombardo before Calles threw down the gauntlet to the Cárdenas regime; but after the ex-president and foreign business interests began their drive against organized labor, a Committee for Proletarian Defense was formed on the initiative of the powerful Mexico City Electricians Union, and the C. T.M. was the permanent institutional expression of the unity achieved in the struggle against Calles and the reactionaries. ${ }^{40}$ At first Lombardo and his associates were skeptical of the Cárdenas promises and were prone to analyze the Mexican situation in terms of a cycle of revolutions that would eventually sweep labor into power. But the point of view of Lombardo and the labor movement he led was to change. According to Nathaniel and Sylvia Weyl, Cárdenas conviced labor of his revolutionary integrity by his actions, while the rise of Fascism in Europe compelled a revolution of labor strategy and tactics on an international scale. ${ }^{11}$ In my judgment it was certainly the international situation which tempered the views of both Cárdenas and Lombardo.

Cárdenas knew that the revolutionary program could not be carried out in Mexico by fiat from above and realized that he needed the backing of a powerful labor movement to smash the conservative opposition, a circumstance not unlike that in the United States at the time. In the words of the Weyls, "If the theory of government as the arbiter of class conflict was appropriate to a society in equilibrium, that of a conscious alliance between the state and the working-class organizations applied to a society in transition toward collectivist forms." ${ }^{42}$

Sanford Mosk claimed that the C. T. M. embraced the majority of the organized workers of Mexico, and that, therefore, it was reasonable to accept the official position of that organization on the point of view of Mexican labor as a whole. Furthermore, he felt that Lombardo Toledano was the leading figure in setting up the Federation and in shaping its policies during its formative years, and that he, more than any other person, had influenced the thinking of the C. T.M. on eco-

${ }^{39}$ From an address by Lombardo Toledano to the First Congress of the General Confederation of Workers and Peasants of Mexico, quoted in Nathaniel and Sylvia Weyl, The Reconquest of Mexico, p. 352.

${ }^{40}$ Nathaniel and Sylvia Weyl, The Reconquest of Mexico, p. 237.

41 Ibid., pp. 236-237.

42 lbid., p. 240. 
nomic questions; therefore, his point of view could be taken to represent the C. T.M. point of view. ${ }^{43}$ The first Congress of the organization of the C. T. M declared: "The C. T. M. is a national labor front for the struggle between the classes at the service of the Mexican workers." ${ }^{44}$ It went on to say that the C. T.M. would establish the method of conducting the fight against feudalism and imperialism and for the economic and political independence of the Mexican nation, guaranteeing in this manner the historical development of the Revolution. ${ }^{45}$ Plenn maintained that the attitude of the Confederation became one of collaboration with President Cárdenas, and it was determined not to clash with the rest of the forces which should organize to back the Cárdenas government, and with which the C. T.M. had common interests. ${ }^{46}$ Here we note one of the first suggestions of a departure from the earlier labor' philosophy of Lombardo towards a sort of popular front, demonstrating his ability to change tactics when the material circumstances changed. Particularly did he desire to support the Cárdenas regime after the oil expropriation crisis. Soon Lombardo was to say:

... the proletariat is not self-sufficient to fight international Fascism and reaction; the proletariat is the nerve center of the people, as the class which produces human wealth. ... And since this is to be a popular party, it is evident that this will not be an attempt to establish or organize soviets. . . The soviets in order to realize their aims must rest necessarily on a prior revolution that would transform the property system. ... We are going to create a popular alliance to defend the interests of the Mexican Revolution. . . .

Being a worker is not enough to guarantee the carrying out of a program of workers as a social class . . this will be the first opportunity for the working class, as a social class, to intervene in the orientation and direction of the country's policies. ${ }^{47}$

Apparently, then, the "external " circumstances of the threat of German and Italian Fascism caused Lombardo to vary his former theory, or at least his tactics, and adopt a policy advocating government intervention and the popular front. Indeed, had not this threat influenced the course of Mexican history, it is quite likely that the reaction of England and the United States to oil expropriation would have done so in any case.

${ }^{43}$ Mosk, Industrial Revolution in Mexico, pp. 100-101.

44 López Aparicio, El movimiento obrero en México, p. 220.

${ }^{45} \mathrm{lbid}$.

${ }^{46}$ Plenn, Mexico Marches, pp. 298-299.

${ }^{47}$ Lombardo Toledano as quoted in Plenn, Mexico Marches, pp. 298-299. 
Actually the internal threat to the Cárdenas policy was sufficient to warrant labor's warm support of the regime and to cause them to proclaim as early as April, 1937:

The proletariat knows well that under the capitalistic system it is impossible for it to receive all that it produces, but there is the possibility of utilizing the government to enforce the articles of the Constitution, which would alleviate the situation of the masses of workers. ${ }^{48}$

By 1938 Lombardo could say in addressing the Extraordinary Meeting of the National Council of the C. T. M.:

There are two attitudes equally dangerous for the proletariat-that of the extreme right and that of the extreme left. The theory that the working class should be put at the service of ambitious individuals (Fascism), along with the theory of the self-sufficiency of the proletariat, of its indestructible force, and that after Cárdenas the dictatorship of the proletariat must be instituted are both theories traitorous to the Mexican people and to the Revolution. ${ }^{40}$

Apparently the Mexican labor leader now thought that the dictatorship of the proletariat, at least for the time-being, was not the solution to the Mexican labor problem. At this same meeting he heaped praise upon the policies of the Cárdenas administration when he said:

Cárdenas represents the purest ideals of the Mexican Revolution. That which distinguishes this regime is its effort to eliminate feudalism, establish national industry, lift the condition of the producing masses, develop the civic virtues of the people, and make the Mexican nation a fraternity with the other peoples of the earth. ${ }^{50}$

Thus the C. T. M. and the Cárdenas administration were wedded and were co-dependent, perhaps much like the Pope and Crown of Spain in the 15 th and 16th centuries-and like Roosevelt and the labor movement of the United States in the 1930's!

In explaining the broader aims of the C. T. M. Lombardo expounded his views as follows at the above-mentioned conference:

The program of the C.T.M. from the beginning was not limited to the interests of the proletariat exclusively, but to the interests of all the people. . . . For that reason the C. T. M. has carried out alliances with

${ }^{48}$ Confederación de Trabajadores de México, La C.T.M. y la carestía de la vida (México, 1937), pp. 19-20.

${ }^{49}$ Lombardo Toledano, "Discurso del Lic. Lombardo Toledano," América Latina, No. 1 (abril 1, 1939), p. 10.

50 lbid., p. 9. 
groups other than the proletariat. It is a party of multiple sectionnot in the limited sense, but in the sense of being occupied on the one side by activities purely syndical and on the other by purely electoral activities. There is no social problem of any type which does not interest the C. T.M. As a force interested in transforming society it must participate in electoral activity. ${ }^{51}$

Hence we see the complete departure from the early Lombardo theory of strict economic trade unionism, and the expression of the popular front idea, along with interest in political and social activity.

Further illustrative of Lombardo's flexibility is a speech made early in 1941 before the Economic Congress of the C. T. M. where he said:

The worker movement with the revolutionary conscience which the C. T.M. represents will change its conduct every time that experience advises it to change its conduct, and each time that the facts from outside are transformed and indicate the necessity for a new tactic. The rigid forms-the permanent forms-are against the nature of things-are against scientific truth, and consequently against revolutionary interests. ${ }^{52}$ (Italics mine.)

Some specific proposals of the Economic Congress which throw light upon the "tactic" of the time were, (1) greater and more direct intervention of the state in the direction of the national economy-this intervention taking fundamentally the form of nationalization of principal sources of production and the administration of them by the state itself through organizations of decentralized type, (2) organization of the workers in syndical form in these industries solely for the purpose of criticizing and watching the actions of the management, (3) strict vigilance of the state over worker cooperatives of independent production to the end of assuring their benefit for workers, (4) cooperation of the state in companies managed by workers for the purpose of lending them direct technical and financial aid, and (5) greater vigilance of the state over private companies to see that necessary reinvestments are made and to keep them from being abandoned. ${ }^{53}$ Here may be noted a recommendation for nationalization of "principal sources of production," and the organization of workers into unions for the sole

51 Ibid., p. 8.

52 Vicente Lombardo Toledano, "Discurso pronunciado en la sesión inaugural del Congreso Económico de la C. T. M., reunido del 29 al 31 de enero de 1941 en el Palacio de Bellas Artes," Importantes resoluciones al Congreso Económico de la Confederación de Trabajadores de México (México, 1941), n. p.

ss Ibid. 
purpose of "criticizing and watching the actions of the management," along with the suggestion of state supervision of private investment.

Lending some evidence to the thesis that Lombardo intended to vary the tactics of the worker movement only, and that he did not change his basic socio-economic philosophy during the 1930's, was the following section of a speech made during the same meeting:

The intervention of workers in the national economy is not a revolutionary intervention in the exact sense of the term because in this manner we are not going to pass from a capitalist regime to a socialist regime. No, the historic change has to be a revolutionary change; not a juridical change. ${ }^{54}$

Indicating that he looked forward some day to the "real revolution of the proletariat," Lombardo went on to say:

A popular revolution will be achieved just as the democratic bourgoisie revolution was achieved-a revolution which will make Mexico independent as an autonomous nation, and which is going to prepare the workers, giving them experience for more decisive steps in the future. Therefore, it is necessary to insist on the participation of the workers in the national economy. ${ }^{55}$

Apparently Lombardo had decided that it was more expedient merely to have the unions press for state intervention in national production rather than have actual worker administration of the sources of production. In speaking of the "fifth column" in Mexico, these were his words:

What is our position concretely? What do we want? The dictatorship of the proletariat? Communism as the regime of Mexico?

We want national unity ... government of the people; popular government, not workers' government. . . . We do not seek a government of faction. The working class of our country does not want a government of its own. ${ }^{56}$

This was a remarkable shift from his position of 1934; but the world had changed since 1934! In answer to the question if he were a Communist, he declared in the speech mentioned above:

I have said it a thousand times and everyone knows it-in Mexico, in Latin America, in Europe, in the United States. I have never been nor

54 lbid.

55 lbid.

${ }^{56}$ Lombardo Toledano, 5th Column in Mexico (New York, n. d.), p. 17. 
am now a member of the Communist Party. I have never made commitments of any kind to the Communist International. If I had ever been a member of the Communist Party, or were now, I would announce it with pride, sincerely and boastfully.

But I am not. I have many times disagreed with the position taken by the Party's leaders. ${ }^{57}$

Before attempting a summary statement on the socio-economic philosophy of the Revolution under Cárdenas, let us note briefly the President's attitude towards capitalism, as well as the attitude of Jesús Silva-Herzog, economic advisor to Cárdenas and his representative in the United States during the oil expropriation crisis. Cárdenas said:

Formation of our own economy will free us from a certain kind of capitalism, the incentive behind which is none other than to obtain raw materials by means of cheap labor; a capitalism that does not even decide to reinvest its profits in Mexico, that becomes a menace to nationality in troublous times and that only leaves behind it, in the last event, exhausted lands, a depleted subsoil, starvation wages and unrest foreboding disturbance of order. ${ }^{58}$

Professor Jesús Silva-Herzog also gave his opinion concerning capitalism and what Mexico did not want, but, like Cárdenas and other Mexican leaders, did not give a systematic blueprint theory for a program of action save in the most general terms. He wrote:

All men, in some way, desire to better their condition. The same is true with the social group. History is the story of people trying to increase their well-being, even though by different methods. ... . In the process they forgot man and made him the victim of the system. . . .

The Renaissance in economics, politics, and learning began in Western Europe in the 13th century-new blood ran through the body politic of the West. Luther and Calvin, in the 16th century, reformed religion to meet the needs of a rising capitalism, and the generous voices of Sir Thomas More, Erasmus, and Juan Luis Vives were lost in the cries of the merchants and street vendors.

One cannot deny that capitalism was a creative system; but this was in the past and not in the present. The material progress realized in England and some other countries at the end of the 18th century, and a little later, was magnificent, but only in the sense of science and technology-not in that which is essential to the most intimate life of man. ${ }^{59}$

57 lbid.

58 Policies of the Present Administration of Mexico, p. 15.

59 Jesús Silva-Herzog, “Lo humano, problema esencial," Quadernos americanos, I, No. 1 (enero-febrero, 1942), 9-16. 
A more specific indictment of the capitalist system followed:

It is perhaps correct to say that since the end of the past century capitalism ceased being the instigator of progress because of its internal contradictions; the periodic crises, the increasing conflict between workers and employers, and the international rivalry between the great economic units of the most powerful empires, have resulted in dire consequences for the individual and society. At no time in history has there been produced such profound pain and sorrow as in our days, and this has occurred while we can still hear the echo of the voices of the superficial optimists of the years 1927, 1928, and a good part of 1929, which claimed that at last capitalist society had found the formula for perpetual human well-being. ${ }^{\circ 0}$

Silva-Herzog then proceeded to reject the theories of Fascism, Soviet Communism, and classical liberalism in these words:

And now several solutions offer themselves-Fascism; the system of Marx and Engels with its many successes, but at heavy costs, cruelty, and inevitable errors, and it is a long way from final victory; and finally a third system, founded on the ancient principles of political democracy and political liberty also-a system which has been until now for the benefit of the minorities, which has the odor of an old thing, wormeaten by the implaceable work of time. We would have no objection if it were a new democracy and a new liberty-a liberty of economic democracy as well as political and social democracy-a democracy and a liberty without subterfuge, which embraces all horizons of culture.

... We must defend our cultural traditions which are of value. We must refuse all current ideas of force even if it appears that to become involved would be to our advantage. We must be conscious of our common purpose and cooperate with those illustrous Spaniards who found refuge in our country after the disaster of the Republic. . . . ${ }^{11}$

But the new system to be devised was not named. What summary statement can be made with regard to the socio-economic theory of the Mexican Revolution under Cárdenas at this point? Dr. Samuel Guy Inman in his classic work on Latin America probably came very near to the best answer possible when he wrote:

The aims of the revolution are in some respects self-contradictoryto socialize all life and at the same time to develop private industry. . . . The via media agreed on by the devotees both of revolution and of private initiative is half socialism, half capitalism (pseudo-socialism, the radical calls it; bolshevism, cries the conservative). It was to be an improvement on Soviet Russia and would permit Mexico to 
keep on fairly good terms with its powerful capitalistic neighbor of the North. ${ }^{82}$

\section{III}

\section{Labor Organization.}

\section{LABOR THEORY}

After having examined at some length the general socio-economic theory of the Mexican Revolution during the presidency of Cárdenas, it is now our purpose to analyze in some detail the attitude towards labor organization, its nature and place in the Mexican economy. Early in his administration, Cárdenas said in a public address:

Here I deem it timely to repeat that organization of workers, like organization of peasants, is indispensable for enforcement of the laws of this country. . . . A superior force, which can be none other than organized labor, must of necessity cooperate in order to overcome the resistance that unfortunately opposes economic betterment of our people. ${ }^{\text {os }}$

Then in a passage reminiscent of the Webbs, Cárdenas reminded the workers that labor unions were the best weapon to insure that the authorities enforced the labor laws and the Six-Year Plan of the government. And once organized into unions and peasants' leagues, they were encouraged to establish consumer cooperatives in every village, and then producer cooperatives. ${ }^{64}$ It is noteworthy that Cárdenas and Lombardo were never quite able to agree on the point of producer cooperatives, since Lombardo did not believe that this process could "lead the Mexican workers into socialism." Apparently the C. T. M. leaned towards mixed forms of industrial administration in which the State and the consumers had a voice. ${ }^{65}$ As a matter of fact, Cárdenas himself was somewhat inconsistent on this point. During his presidential campaign in one speech he told the people:

I consider that it is contrary to social justice that productive machinery be found inactive. This in itself constitutes a right for the state to intervene. If I am elected president, all those factories which have been closed and whose owners are not able to operate them shall be

\footnotetext{
62 Samuel Guy Inman, Latin America: Its Place In World Life (revised edition; New York, 1947), p. 278.

e3 From a speech by Cárdenas as quoted in Ministry of Foreign Relations, The Mexican Government in the Presence of Social and Economic Problems: Tour of the President of the Republic-Monterrey-Tampico-Guadalajara (Mexico, 1936), pp. 35-36.

${ }^{64}$ Policies of the Present Administration of Mexico, p. 12.

${ }^{65}$ Nathaniel and Sylvia Weyl, The Reconquest of Mexico, pp. 276-277.
} 
rented and turned over to laborers organized into cooperative associations. ${ }^{\text {B }}$

Yet, according to a report by the Ministry of Foreign Relations, Cárdenas said in an address to the workers of Monterrey:

The working classes know that they cannot appropriate factories and other instruments of work because they are not, for the time being either technically fitted for the management, or in possession of the financial resources needed for success of an undertaking of such magnitude. $^{\text {.7 }}$

Strode maintained that Cárdenas did not desire to take over any private industry for either the workers or the government, for he realized that neither was trained sufficiently in socialism to succeed. But with private enterprise fighting him bitterly and refusing to cooperate, the threat of expropriation was his most potent weapon. ${ }^{68}$

\section{The Six-Year Plan and the United Labor Front.}

The Six-Year Plan of 1934-1936 of the P. N. R. outlined the work for the Cárdenas administration. The President was convinced of the political importance of the labor movement when, at the beginning of his break with Calles, the National Committee for the Defense of the Proletariat lent him its backing and endorsement. This was when Cárdenas began in earnest his efforts to create a united labor front. ${ }^{69}$ And, incidentally, it was only with the wholesale intervention of government on its behalf-just as in the United States-that organized labor became a factor in the social life of the country. The Six-Year Plan attacked the problem with such care-it accepted without reservation the thesis of the class struggle and sought the collaboration of the working class to accomplish its ends. At the same time it maintained that the state should intervene when required "to prevent the oppression of the class to be aided by the union." 70 Desiring to make the P.N.R. something similar to a popular front, Cárdenas modified its structure and called it the Partido de la Revolución Mexicana (P. R. M.), or Party of the Mexican Revolution, and charged it with the responsibility of carrying out the Six-Year Plan. The ideology of the P. R. M. was set forth in its declaration of principles where it was declared that the

${ }_{66}^{6}$ Townsend, Lázaro Cárdenas, p. 86.

${ }^{67}$ Ministry of Foreign Relations, The Mexican Government in the Presence of Social and Economic Problems: Tour of the President of the Republic, p. 11.

${ }_{68}$ Strode, Timeless Mexico, pp. 326-327.

${ }^{69}$ López Aparicio, El movimiento obrero en México, p. 247.

${ }^{70}$ Partido Nacional Revolucionario, Plan Sexenal, 1934-40 (Mexico, 1934), p. 46. 
struggle of classes was inherent in the capitalistic system of production, and it upheld the right of workers to contend for political power to be used in the interest of the majority, thus extending the United Front to groups not belonging to organized labor, but nonetheless having the same ends. Further, it considered as one of its fundamental objectives the preparation of the people to establish a "democracy of workers and to arrive at a socialist system." ${ }^{7_{1}}$

Ramón Beteta explained that both the government and the Party considered it impossible, within the capitalistic system, to prevent class struggle, but they "take sides in the fight, the side of the workers." ${ }^{2}$ He stated in addition that Mexico's Six-Year Plan had one fundamental aim: to change the economic conditions of the country for the benefit of its laboring classes, so that they might live a fuller life in dignity and comfort. $^{73}$ And, above all, Cárdenas was to add: ". . . we must make clear in the mind of the universal proletariat that the elimination of imperialistic wars depends upon the peaceful unity of the workers of the world." ${ }^{74}$

\section{The State and Labor.}

All the means of the Cárdenas regime favored the Confederation of Mexican Workers-grants of money, guarantee of union activity, persecution of the enemies of the C. T.M. On the other hand the "Lombardistas" were a decisive factor in the election of governors, mayors, and congressmen favorable to Cárdenas. "At times the entire force of the government was put at the service of this (C. T.M.) grand central." " ${ }^{5}$ It was Cárdenas who, in calling a Congress to unify the labor movement, stimulated the formation of the C.T.M., and thus there was inaugurated a new era in the Mexican labor movement, which then assumed a strong political as well as economic position. The President claimed:

All of us have propagated, defended, and sustained in courts, in the press, and in all forms of the social struggle, the right of the workers and farmers to improve their standards of life with better salaries, their own land and more just working conditions. When the works pass

${ }^{71}$ Partido de la Revolución Mexicana, Pacto constitutivo, declaración de princípios, programa y estatutas (México, 1938).

72 Beteta (ed.), Programa económico y social de México, p. 147.

${ }^{73} \mathrm{lbid}$.

${ }^{74}$ Lázaro Cárdenas, Address Made Before the First National Congress of the Confederation of Mexican Workers, February 24, 1938 (Mexico, 1938), p. 9.

${ }^{75}$ López Aparicio, El Movimiento obrero en México, p. 221. 
to acts the timid spirits are frightened. I consider it a fortunate circumstance of my administration that these essential rights of workers have been the principal product of my government. ${ }^{76}$

One of the desires of the C. T.M. had been to organize a popular front similar to that in France during the administration of Leon Blum. This idea was adopted at the conclusion of the Seventh Congress of the Communist International in August 1935 in Moscow. In accordance with these plans, the C.T.M. called for the principal worker organizations in Mexico to form a popular front. These organizations included the National Confederation of Peasants (C. N. C.), the General Confederation of Workers (C. G. T.), the Regional Confederation of Mexican Workers (C. R. O. M.), as well as the Mexican Communist Party and the P. N. R. ${ }^{77}$ The political position of the C. T.M. was explained as follows during the celebration of the Fourth National Congress in April, 1937:

The C. T.M. of Mexico is a united front of the proletariat; a general front and not a homogeneous organization with a unified opinion. . . The intervention in the political struggle does not mean that it believes in the transition from a bourgeois society to a socialist society through the medium of parliamentary action. It means that its intervention in the present government has as its purpose to fight together against the enemies of the Mexican Revolution. ${ }^{78}$ (Italics mine.)

Thus it becomes fairly clear that the collaboration with the Cárdenas administration was purely a matter of expediency insofar as the leaders of the C. T.M. were concerned, and did not indicate a change in fundamental revolutionary principle.

From 1938 the Revolutionary Party had relations with the worker movement through the C. T. M., which was really the worker section of the Party. This was true in spite of the fact that the original text of Section I, Article 249 of the Federal Labor Law prohibited expréssly the participation of unions in political questions, which fact was simply overlooked. ${ }^{79}$ A law was passed in November of 1940 , however, changing Section I of the article to allow for ample intervention of unions in political questions.

${ }^{76} \mathrm{~J}$. Manuel Corro Viña, El Presidente Cárdenas; nos lleva hacia la dictadura del praletariado? (México, 1936), pp. 96, 97.

77 López Aparicio, El movimiento obrero en México, pp. 221-223.

${ }^{78}$ Confederación de Trabajadores de México, IV Consejo Nacional (México, 1937), p. 119.

${ }^{79}$ Victor Manuel Varela (ed.), Ley Federal del Trabajo: texto oficial conteniendo todas las reformas $y$ adiciones basta la fecha. notas y concordáncias (México, 1951), Section I, Article 249, p. 82. 


\section{Labor Legislation.}

On the subject of labor legislation President Cárdenas made the following observation concerning the function of the state and the nature of such legislation, this theory appearing in a presidential memorial on March 14, 1936:

The modern conception of the functions of the State and of the very nature of labor legislation, from a broadly universal standpoint, requires that doubtful cases be decided in favor of the weaker party. To mete out equal treatment to two parties that are not equal, is neither to administer justice nor to act equitably. ${ }^{80}$

The tone here is certainly much like that of the later Wagner Act in the United States concerning the equalizing of bargaining power. As to the type and purpose of such legislation Cárdenas added:

... revolutionary labor legislation in Mexico must be tutelary in character as regards workers who have been the victims, from time immemorial, of ruthless exploitation ... for law is not created nor made by the State, but is the result of the will of the administration to fulfill the obligations assumed by the Revolution with the working and peasant masses, as is the case in Mexico; or is a direct consequence of a deep revolutionary convulsion attended by sanguinary disturbances that shake the peace of the nations and force conservative parties to give ground and broaden the field of the rights and life of the working classes. $^{81}$

It seems quite clear that the Cárdenas administration developed a paternalistic and aggressive attitude towards the labor movement from its earliest days, and felt that its role was, as Amorós mentioned, to act as judge between capital and labor, throwing its weight on the side of labor, at least so long as that class was the weaker of the two. Cárdenas promised, however, " that capital which adjusts itself to the new norms of justice, which guarantees good salaries, and recognizes the essential rights of the working classes, merits the most complete guarantee and encouragement of the Government." 82

\section{The "Fourteen Points."}

Soon after the speech of Cárdenas on New Years Day 1936 a fresh epidemic of strikes broke out, the focus of the trouble being in the

${ }^{80}$ Confederación de Cámaras Nacionales de Comercio e Industria, Análisis económico nacional, 1934-1940 (México, 1940), p. 36; Policies of the Present Administration of Mexico, p. 31.

st Policies of the Present Administration of Mexico, p. 23.

82 Corro Viña, El Presidente Cárdenas, p. 97. 
largest industrial center of Mexico, Monterrey. Workers at the glass factory had gone on strike and agitators sent by Lombardo Toledano were causing no end of trouble to other manufacturers. Monterrey had been opposed to Cárdenas and was, as an industrial center, a good place for reactionary sentiment to gain force. On February 6, 1936, Cárdenas asked his Minister of Labor, Genaro Vásquez, to meet him in Monterrey. After several days of investigations and interviews with leaders of both labor and capital, Cárdenas presented a plan for settling not only that strike, but the labor question in general. It was issued on February 11, 1936. It became famous during the first half of the Cárdenas administration under the title of the Fourteen Points. ${ }^{83}$ It was Cárdenas' own labor platform, although at first, according to Townsend, it was attributed to Dr. Ramón Beteta. ${ }^{84}$ Because they summarize in one place the basic ideas of Cárdenas towards labor in the national economy, these points will be presented at length:

1. The government will cooperate with labor and capital in the solution of their problems.

2. A united labor front should be organized, since strife between rival labor organizations themselves is detrimental to the government as well as to the workers and employers.

3. The government is arbiter and regulator of social problems.

4. The demands of labor will be taken into consideration only as they come within the limits of the ability of the various industries to pay.

5. When labor's united front is organized, the government will deal with it to the exclusion of minority groups which might choose to continue.

6. Employers shall have no right to intervene in the affairs of labor organizations.

7. Employers shall have the same right as the workers have to associate themselves into a united front.

8. The government desires the further development of industries within the nation, since it depends upon their prosperity for its income through taxation.

9. Current labor agitation is not due to the existence of Communistic groups, since they are so small they have no real influence in the affairs of the nation. The real cause of labor agitation is the fact that the just needs of the laboring masses have not been met, and the labor laws have not been carried out faithfully.

\footnotetext{
83 For the complete document see Ministry of Foreign Relations, The Mexican Government in the Presence of Social and Economic Problems, p. 12.

84 Townsend, Lázaro Cárdenas, p. 130.
} 
10. Small groups of Communists do exist within the country-as they do in Europe and the United States-but their activities in Mexico do not endanger the stability of our institutions nor do they alarm the government, and they need not alarm the industrialists.

(Number 11 is not appropos to this discussion, therefore is omitted.)

12. The attitude of the employers of Monterrey is duplicated in centers such as La Laguna, León, the Federal District, and Yucatán.

13. Capital should be very careful not to continue provoking agitations because these would come to constitute a rallying point for political interests, and this would bring on civil warfare.

14. The industrialists who do not wish to continue to operate because of the demands of the unions can turn over their industries to their laborers or to the government, for it to operate. This would

, be a patriotic step, but simply to close down the factories would not be. ${ }^{85}$

The principle expressed in point number one introduces the state into labor-management relations; number two suggests a united labor federation as a method of avoiding many jurisdictional disputes, and perhaps a belief that the government could better control such a labor organization; point three illustrates well the contention that the general character of the regime was interventionist, with the state being the final judge of social justice for all the classes in society; number four was the expression of the principle, to be adopted later, of basing wage increases on the ability of the company to pay; the fifth point emphasized what was to become the paternal relationship between the government and the C. T.M., and demonstrates the philosophy behind the political turn taken at the time by the Mexican labor movement; point fourteen undoubtedly presaged the Expropriation Law of 1936, and was a statement of the principle of outlawing the "shut-down." It is surprising indeed to observe the similarity between the labor theory of President Perón of Argentina and this program of Cárdenas, expressed ten years before Perón's. ${ }^{86}$

After the issuance of the Fourteen Points the Department of Labor became an agency for the organization and defense of labor. The labor movement was thus definitely wedded to politics, or the state, and vice versa. The chief executive in public declarations began to glorify the struggle of the classes, and the Secretary of Education printed mil-

\footnotetext{
${ }^{85}$ Ministry of Foreign Relations, The Mexican Government in the Presence of Social and Economic Problems, p. $12 \mathrm{ff}$.

${ }^{86}$ For a discussion of Perón's labor philosophy see Joe C. Ashby, "Labor and the Philosophy of the Argentine Revolution," Inter-American Economic Affairs, V (Summer 1951), 71-96.
} 
lions of texts praising Marx, Lenin, and Stalin as apostles of a modern religious creed for the salvation of humanity. ${ }^{87}$ The Law of Expropriation of November 23, 1936, gave to the government the major judicial power for realizing the plan of socialization of wealth, and under it land was distributed; railways and the petroleum industry were nationalized.

\section{The Constitution of 1917: Article 123.}

Behind Cárdenas, the official government party, Lombardo Toledano, and the administration advisors in formulating their labor philosophy and program lay Article 123 of the Constitution of 1917, as well as the Federal Labor Law of 1931. Since both Cárdenas and the P.N.R. constantly insisted that they were merely carrying out the provisions of these two basic documents, it may be well to examine at least pertinent sections of them. The P.N.R. in its original declaration of principles pledged itself to follow the regulations set out in Article 123 of the Constitution. ${ }^{88}$ When the convention was called at Querétaro in 1917 to write a new Constitution, Carranza, in charge of the executive power, submitted a draft largely based on the political document of 1857 . But the radical social forces swept the politically minded delegates before them, and the document that was finally approved, with the famous Articles 3, 27, and 123, became, according to Inman, "the most radical Constitution adopted by any state up to that time." ${ }_{89}$ The longest article in the Mexican Constitution, and in some ways the most radical, is Article 123 which provides for a modern labor program, not only allowing labor to organize, but prescribing in detail the eight-hour day, the protection of women and children in every industry, and most of the modern ideas of labor protection. As Inman remarked, Article 123 was written not so much to meet the actual conditions in Mexico as to express an ideal and to strike at the foreign industrialists and Mexican bacendados who were indifferent to the laborers' welfare. ${ }^{90}$

In addition to the provisions previously mentioned, Article 123 prescribed that for each six days of work there should be one day of rest; that women, during three months before childbirth, should not do heavy work and should have one month off from work following childbirth at full salary, her place of employment being kept open for her re-

${ }^{87}$ López Aparicio, El movimiento obrero en México, pp. 215-216.

88 Partido Nacional Revolucionario, Constitución (México, 1934), p. 12.

89 Inman, Latin America, p. 261; See Trueba (ed.), Constitución política de los Estados Unidos Mexicanos (México, 1944).

${ }^{90}$ Inman, Latin America, p. 264. 
turn. $^{91}$ It was further stated that the minimum salary should be "that considered sufficient, according to the conditions in each region, to satisfy the normal necessities of life of the worker . . . and the workers shall have the right to participate in the regulatory boards." ${ }_{92}$ The principle of equal pay for equal work regardless of sex or nationality was set forth in Section VII. Double pay should be given for any work over eight hours, and in no case could overtime exceed three hours per day for more than three consecutive days. Women and men under sixteen were prohibited from working overtime..$^{93}$ In all agricultural, industrial, and mining industries, or whatever other class of work, the employers were obligated to furnish workers comfortable and clean houses, and the rent could not excced one-half of one percent per month of the taxable value of the property. They were also obligated'to establish schools, hospitals, and "other services" necessary for the community. ${ }^{94}$

Employers were made responsible for accidents of work and for professional illnesses of the workers which were incurred in line of duty. In addition, a death benefit payment of a certain amount was required. ${ }^{95}$ Like the workers, the employers were permitted to join together in professional associations. The right to strike and the shutdown were recognized. ${ }^{96}$ Article XVIII stated that strikes were legal when they had as their object "the establishment of equilibrium between the diverse factors of production, harmonizing the rights of labor with those of capital." 97 This Article went on to provide that in the case of public utilities, the strikers had to give ten days' notice to the Board of Conciliation and Arbitration, and that the strike would be considered illegal if the majority of the strikers exercised violence against persons or property, or in the case of war industries. ${ }^{98}$ The shut-down was to be considered legal when an "excess of production makes it necessary to suspend work in order to maintain an income equal to the cost of production," provided the approval of the Board of Conciliation and Arbitration had been received.9.

The Constitution provided that differences or conflicts between capital and labor were subject to the decision of a Board of Conciliation and Arbitration formed by an equal number of representatives of the em-

\footnotetext{
91 Trueba (ed.), Constitución Politica de los Estados Unidos Mexicanos, Sections IV and $\mathrm{V}$.

92 lbid., Section VI.

${ }^{9}$ lbid., Section XI.

94 Ibid., Section XII.

95 Ibid., Secrion XIV.
} 
ployer and the laborers, and one government representative. This arbitration was not compulsory and consequently the government could not decide on the issues involved in a strike unless both parties agreed to it. If one of them did not accept arbitration, the strike went on until one of the adversaries gave in. ${ }^{100}$ If the employer refused to subject his differences to arbitration, however, or to accept the award of the Board, he had to terminate the work contract and was obliged to pay the worker the equivalent of three months' salary. ${ }^{101}$ An employer who fired an employee "without justification," or for having taken part in a trade union organization or a legal strike, was obligated, at the election of the worker, to rehire him or to pay him three months' salary. ${ }^{102}$ Transportation to and from the place of work was to be free to workers. ${ }^{103}$ On August 31, 1929, the Federal Congress, rather than the various states, was given authority to enforce these provisions, and the Federal Labor Law of 1931 was born of this act.

Felix Palavicini, in the prologue to Trueba's classic work on Article 123 of the Constitution, commented that: "Until this date no Constitution in the world included the social guarantees . . . the Constitution of Querétaro was the forerunner for the structure of modern constitutions. ${ }^{104}$ The next constitution to do so was the Weimer Constitution of 1919 in Germany. According to López Aparicio, "This event marked the beginning of the end of the doctrine of laissez-faire and the beginning of the belief in state intervention in the economic process for the good of the community." ${ }^{105}$ Without much question the supreme law of 1917 broke the classical molds when it included such precise requirements as those contained in Chapter VI, Article 123, on labor and social welfare. Article 123 was designed, according to Trueba, to guarantee the aspirations of the working classes of Mexico, victims of a prolonged situation of injustice. Palavicini added: "It [the Constitution of 1917] in truth expresses the significance of 'our freedom movement: a change of the judicial system and the economic and social system for a new one." ${ }_{108}$ Trueba further analyzed the meaning of the Article when he said:

${ }^{100} \mathrm{Ibid}$., Article XX; and Beteta (ed.), Programa económico y social de México, p. 177. 101 Trueba (ed.), Constitución Politica de los Estados Unidos Mexicanos, Article XXI. 102 Ibid., Article XXII.

103 Ibid., Article XXV.

${ }^{104}$ Felix F. Palavicini in Alberto Trueba Urbina, El Artículo 123 (México, 1943), p. 13.

105 López Aparicio, El movimiento obrero en México, pp. 163-164.

${ }_{106}$ Palavicini in Trueba, El Artículo 123, pp. 13, 123. 
This article offers a minimum amount of protection to the workers against whoever tries to use human labor illigitimately. A system which guarantees individual liberties only provokes basic social divisions. This law guarantees the rights of the collectivity-the workers. It attempts to insure individual liberty as well as to give social guarantees. ${ }^{107}$

The inclusion of Article 123 in the 1917 Constitution was not the suggestion of Carranza. In fact, the original project of the Constitution contained no provision for the rights of workers. ${ }^{108}$ The delegation from Veracruz, headed by Cándido Aguilar, together with the delegation from Yucatán, insisted on an entire article devoted to workers' rights. ${ }^{108}$

Federal Labor Law of 1931.

The principles of Article 123 of the Constitution relating to the rights of labor were embodied in the Federal Labor Law of 1931. This statute legalized collective bargaining, prohibited lockouts, made the closed shop legal but not obligatory, restricted the right of employers to suspend operations or discharge workers, provided for dismissal wages for employees discharged without just cause, and provided for the establishment of government boards of conciliation and arbitration. ${ }^{110}$ The law has been amended from time to time. A law of February 19, 1936, required payment for the weekly rest day, thus increasing wages by approximately $17 \%$, according to a report of the United States Tariff Commission. The principle of "profit sharing" was incorporated in the settlement of a strike in the electrical industry in July, $1936 .{ }^{111}$

Trade unions were not only permitted but were made obligatory; when requested to do so, employers had to enter into a collective contract with the union. In this regard Cárdenas said: "The department of labor has dedicated its attention to settling the conflicts which have been presented, . . . has dedicated itself to encouraging the signing of collective agreements, which are in accordance with Article 123 and the Federal Labor Law." ${ }_{112}$ On another occasion he remarked: "Collective bargaining with workers will be strengthened until it shall prevail

${ }_{107}$ Trueba, El Artículo 123, pp. 27-28.

108 López Aparicio, El movimiento obrero en México, p. 167.

${ }^{109}$ Secretaría de Gobernación, Diario de los debates del Congreso Constituyente de 1916-17, I, 684, 701.

110 United States Tariff Commission, Economic Controls and Commercial Policy in Mexico, p. 18; Victor Manuel Varela (ed.), Ley federal del trabajo (México, 1951).

111 United States Tariff Commission, Economic Controls and Commercial Policy in Mexico, p. 18.

${ }^{112}$ Lázaro Cárdenas, Realización del Plan Sexenal, 1935-1936 (México, 1935), pp. 34-35. 
to the exclusion of all other forms of contract." ${ }^{113}$ In comparing the collective contract of Europe with that in Mexico, Roberto Amorós distinguished them as follows:

In the collective contract in Europe the parties are the employer and each one of the workers considered individually. In the Mexican contract the parties are the employer and the union. The unions not only determine the conditions of labor over all of their members but intervene to protect their members individually, stipulating provisions expressly in the collective contract. It can be affirmed that the collective contract in Europe fixes general rules or norms to which must be harmonized the individual contracts, but that the collective contract in Mexico is a contract to be executed itself, which absorbs the contents of all the individual contracts, displacing them entirely.114

The right of the worker to his job was assured until the Board of Arbitration determined otherwise, and if discharged unjustly, he had to be paid for three months' salary by the employer. Once a strike had been declared legal by the Labor Board, the employer had to pay the worker for the time lost during the strike. ${ }^{115}$ In the view of López Aparicio, the law put no particular prohibition on the ideology of the labor movement in its effort to defend the common interests of the workers. "It is so general that all the theories of the labor movement could be included, although the fourth section of Article 249 implies that revolutionary syndicalist tactics are prohibited. Fomenting violent action against persons or property is a prohibition imposed upon the unions." 116

On January 18,1935 , because of the lack of legislation in some states, Congress amended the Constitution to give the federal government power to issue laws on labor for all the Republic in accord with Article 123 of the 1917 Constitution, and also in that year a Federal Board of Conciliation and Arbitration was established. ${ }^{117}$

The rights of organized laborers are covered by the general statement that the right to work shall not be interfered with except when the rights of third parties or of society are involved, as defined by law. ${ }^{118}$ When a strike is declared legal and a minority of the strikers attempt

\footnotetext{
113 Policies of the Present Administration of Mexico, p. 12.

114 Roberto G. Amorós, Derecho de clase 2 (México, n. d.), p. 25.

115 Varela (ed.), Ley Federal del Trabajo; Inman, Latin America, p. 265.

116 Varela (ed.), Ley Federal del Trabajo, Section IV, Article 249; López Aparicio, El movimiento obrero en México, pp. 203-204.
}

117 Varela (ed.), Ley federal del trabajo, p. 8.

118 Ibid., Section 6, Article I, p. 12. 
to resume work against the will of the majority, the rights of society are offended and the state may prohibit the return of the minority to work. Also, when a strike is declared legal, the employer may not replace the workers before a ruling by the Board of Conciliation and Arbitration in accordance with the law. ${ }^{119}$ Concerning the attitude of the state towards strikes, Cárdenas said in his Message to Congress in 1936: "The attitude of the State towards strikes has been one of absolute respect and protection for the right to strike, within strict fulfillment of the provisions of the Federal Labor Law." ${ }^{20}$ Article 260 prescribes the objectives for a legal strike by saying that strikes shall be legal if they have for their object: to insure equilibrium among the diverse factors of production, thus harmonizing the rights of labor with those of capital; to obtain fulfillment of contract or to enforce revision of an expired contráct; to support a strike which has been declared legal. ${ }^{121}$ Strike activity must be limited to the single act of suspension of work, and the strike is illegal if the majority of strikers carry out violence against persons or property. ${ }^{122}$

In a matter of collective conflicts due to "economic order" related to the establishment of new conditions of labor, suspensions or stoppages of work, which by their special nature cannot be resolved under terms set up in Chapter IV of the Federal Labor Law shall be handled under the terms of Chapter VII of Title IX, the provisions of which are summarized as follows: The Board of Conciliation and Arbitration orders the maintenance of the status quo and orders an investigation by three experts, which it appoints, aided by two commissions, one of workers and one of employers, equal in number. The time for the investigation must not exceed thirty days. Then, after both parties have had the opportunity to object to the findings of the experts, the Board renders its decision. In such cases, the Board has more power than otherwise, since it may change fundamentally the conditions of labor. ${ }^{123}$ The decision of the Board has the binding force of a judicial decision. The Weyls felt that this section of the code was less favorable to labor than the ordinary procedure since capacity to pay rather than contractual right was the dominant consideration. ${ }^{124}$ As interpreted by these writers

\footnotetext{
${ }^{119}$ lbid., Section 8, Article I, pp. 12-13.

${ }^{120}$ Ministry of Foreign Relations, The Mexican Government in the Presence of Social and Economic Problems: The President's Message to Congress, 1936 (México, 1936), p. 46.

121 Varela (ed.), Ley Federal del trabajo, Article 260, p. 83.

$122 \mathrm{Ibid}$., Articles 262, 263, p. 84.

123 Ibid., Chapter VII, Article 576, p. 187.

${ }^{124}$ Nathaniel and Sylvia Weyl, Reconquest of Mexico, p. 241.
} 
a conflict became "economic" when the employer maintained that he was unable to meet labor's demands, but they added that there was no precise boundary line between conflicts of an "economic order" and other disputes. ${ }^{125}$ They contended that Mexican law did not regard the strike as a test of force between employer and worker, for such a view would contradict the underlying theory of the role of law in conflicts between parties of unequal power. And in answer to the question, "Is there a place for the strike within the framework of Mexican industrial jurisprudence? ", these authors said: "If the strike is defined as a method of bettering labor standards by means of economic coercion, the answer must be negative." ${ }^{128}$ Their reasoning was that if the stoppage was declared legal, the workers relied on the police force of the state; while if it was outlawed, labor would almost invariably be defeated by governmental action. They concluded their analysis by saying: "It has therefore been argued that Mexico has effective compulsory arbitration without its accompanying advantages of uninterrupted production and at least superficial industrial peace." ${ }^{127}$ The Weyls did note, however, that the increasing stake of Mexican labor in the mines and industries of the nation was making the traditional combat philosophy of the trade unions inapplicable, obsolete, and even antisocial, because the classic theory of trade unionism was part and parcel of the competitive capitalist ideology of enlightened self-interest and, when labor groups were given partial responsibility for the management and ownership of industry, they acquired broad correlative duties which spring from their dual position as employees and employers. ${ }^{128}$ Cárdenas hinted at this philosophy in his message to the convention of the Mexican Oil Workers Union on July 1, 1939, when reprimanding a minority group for acts of sabotage:

... the workers must be made to understand that the position of the Oil Workers Union cannot be that of fighting against the'State, which in this case is neither a capitalistic unit nor a profit organization, for an improvement in the condition of oil production will necessarily be reflected in larger incomes for the workers and for the people as a whole. ${ }^{129}$

The general philosophy embodied in the 1931 Labor Code was inter-

125 lbid.

126 Ibid.

127 Ibid., p. 243.

128 Ibid., pp. 243-244.

${ }^{129} \mathrm{Ibid}$., p. 244. See also Beteta (ed.), Programa económico y social de México, pp. 175-177. 
preted by Supreme Court Justice Xavier Icaza in a pamphlet for workers as follows:

Mankind is divided into only two categories, those who work and those who do not work, those who are useful to the society in which they are born and the parasites whose sole occupation is to appropriate and enjoy the creative labor of their brothers. . . . Two unequal parties must be judged in terms of their inequality with an attitude of protection toward the weaker side. This the law demands, and in this manner the judge must act. ${ }^{130}$

The Weyls maintained that a literal interpretation of the labor code would make virtually all strikes legal and mobilize the power of the state to force the business community to grant economically unreasonable demands, and that far from resulting in a proletarian utopia, this would lead to the stagnation of industry and destroy the incentives of investment. ${ }^{131}$ It would seem that their opinion is subject to question on two counts. First, if the economy of Mexico were moving in the direction of state ownership of the means of production-as they themselves reasoned when discussing the right to strike in Mexico-investment would not depend upon private incentive; therefore, it would not follow that a strict enforcement of the labor code would cause industry to reach a state of stagnation. In the second place, it might be questioned whether the state could ordinarily force the private businesses which did exist to grant economically unreasonable demands, since if a question of "economic order" were involved, the Board would generally follow the recommendations of the commission of experts, who supposedly would not make demands that were unreasonable.

López Aparicio summarized the philosophy of the Federal Labor Law in these words: "In direct contrast with the idea of individualism, which puts men above the group, it puts the interest of the group above that of any individual. . . . Yet, any individual is free to join or not to join, or to withdraw." ${ }^{132}$ This view has much in common with that of Selig Perlman concerning the essence of trade unionism.

\section{IV}

\section{Concluding Observations}

The following obscrvations are no more than an attempt to bring together what appear from the evidence studied to be valid conclusions

130 Xavier Icaza, El muevo derecbo obrero mexicano (México, 1930), p. 3; Sec also Nathaniel and Sylvia Weyl, The Reconquest of Mexico, p. 240.

131 Nathaniel and Sylvia Weyl, The Reconquest of Mexico. p, 242.

1:2 López Aparicio, El moviniento obrero en México, pp. :06-198. 
concerning the development of the theory of the Mexican Revolution under Cárdenas, with special reference to labor theory. There has been no attempt to make a definitive analysis of the subject, but rather the aim is to point up what appear to have been major currents of thought on the role of government and organized labor in a changing Mexico with the end in view of furthering the understanding of the whole culture of the nation, and particularly of its economic policy. There should be some valuable implications relative to the direction which our Alliance for Progress efforts might take.

Amorós maintained that efforts to solve the social questions generally could be enclosed within three classes, or concepts: (1) individualism, (2) socialism, and (3) interventionism. ${ }^{133}$ With the name of interventionism, he explained, there could be recognized the coming together of the doctrine which accepted the basic principle of economic liberalism and rejected the socialist solution of the social question, giving to the state the role of regulating the relations between capital and labor, imparting to the laborer a protection which permits him to participate, as far as may be possible, in the commodities of civilization. The state must act as regulator of the existing relations among the diverse classes of the society, protecting in a certain degree the weak elements in their struggle against the strong, impeding the exploitation of one class by another, and conceding a juridical superiority to compensate for economic inferiority. In effect it would prohibit every unilateral limitation on free commerce, such as monopolies; it would promulgate norms which would protect the laborer; it would intervene directly in conflicts which arise between employers and workers by means of arbitral tribunals, created and sustained by the government. ${ }^{134}$ Amorós seemed to feel that interventionism was the term most suited for describing the Mexican program under Cárdenas-certainly a better term than either socialism or Fascism. I presume that this concept would be near to what we in the United States consider our "dual" or " mixed" economy, or twentieth-century capitalism, an outgrowth of the Keynesianism of the 1930's.

In a report of the Confederación de Cámaras Nacionales de Comercio $e$ Industria, a statement was made to the effect that the revolutionary intellectuals who in this epoch directed the Mexican Revolution were in the main Marxists; and it noted that their fundamental postulate was an "equitable distribution of the national wealth." ${ }^{135}$ While it is un-

${ }^{133}$ Roberto G. Amorós, Derecho de clase 1 (México, n. d.), pp. 19-20.

134 lbid.

${ }^{135}$ Confederación de Cámaras Nacionales de Commercio e Industria, Análisis económico nacional, 1934-1940, p. 43. 
doubtedly true that this was an important principle of the revolutionary thinkers of the time, it would seem that this in itself is not sufficient evidence to classify them as Marxists. It is true that almost without exception the spokesmen of the government during the period accepted the postulate of the class struggle, which doctrine has traditionally been attributed to Marx and Engels. (This in spite of the fact that already in 1789 James Madison in his Federalist Letter No. 10 enunciated a class struggle theory of history!) They accused private capital of using its powerful economic position to dominate the political and economic life of the proletariat. But at the same time they felt that in the then-existing condition of the world private capital was necessary. They simply wanted to strip it of its impersonal influence and place it at the service of the people responsible for production, whom they believed to be the workers. In the words of the above-mentioned report, ". . . the strategy of the revolutionary intellectuals was not to destroy private capital, but to regulate it so that it would be the servant of the workers." ${ }^{138}$ Now this is not socialism. Some would argue, in fact, that the principle of private ownership with state regulation is much more akin to the economics of Fascism than to socialism, except that under Fascism the system would not be made the servant of the workers. Actually, it may have been a "fourth" position with organized labor taking the place of the military in Fascism.

Time and time again President Cárdenas stressed the fact that unified labor organizations and the government should work together, under the guidance of the government, in a united front for the betterment of all classes of the society towards the glory of a greater Mexico, this all to be achieved in the main under state regulation of privately owned productive property, at least for the time being. Outstanding evidence of such a philosophy, which smacks of popular-front, benevolent Fascism-even to the glorification of a particular race-was given in a farewell address by Cárdenas to his beloved organized labor movement:

Now that my term of office is drawing to a close, and with the authority derived from my being a friend of you laborers, I wish to beg you to spare no effort toward the elimination of personal animosities. Terminate your quarrels no matter how deep-seated they may be. Do not let your efforts cease until you have attained the complete unification of the proletariat of Mexico. Until this unification is attained, the cause of nationalism cannot advance. . . . As the Revolution desires the maximum of happiness for all Mexicans, it is logical and just that as fast as laborers obtain for themselves greater economic, cultural, and political power, their responsibility to themselves and to

136 Ibid., pp. 43-44. 
the nation is likewise increased. The turning over to them of sources and means of production should carry with it in like degree the obligation to do their part to increase production so that all the inhabitants of Mexico may live better and do away with the wretched conditions that as a millstone have hindered the forward surge of our land. Every laborer with an opportunity to produce, who does not throw all his effort and capacity into his work, or who gives himself over to vice or parasitic practices, is evading his responsibility. He is a traitor to his class and an enemy of Mexico's revindicating movement. ${ }^{197}$

In this speech is clearly seen the tone of nationalism, usually considered an element of Fascism; but at the same time the statement is made that the means of production will be turned over to the laborers and that they must prepare themselves for this responsibility, which principle is definitely socialist. On other occasions the pronouncements of Cárdenas, as well as of officials of his administration-and even Lombardo Toledano-indicate their belief, as we have seen, that the Mexican workers were not yet capable of running by themselves either industrial production or the government, and that the aim of the Revolution at that stage was to encourage private capital ownership, merely regulated by the state in favor of the workers, as well as of all classes of the society. (What effect would such a future prospect have on the marginal efficiency of capital, and hence on the level of private investment, and hence on income and employment?) It may be that Cárdenas favored turning land and agricultural productive facilities over to the workers (as in fact he actually did) and, as Strode thought, did not really intend to nationalize industrial productive property until he felt circumstances forced him to do so. Although privately-owned farms increased $44 \%$ in numbers between 1930 and 1940, it should be noted that much agricultural enterprise was not turned over to private owners, but rather was collectivized in some form or other, differing under various circumstances, and that several statements by Cárdcnas indicated a general belief in moving in the direction of "socialization of the means of production" as a general principle, with no reference to accomplishing such a change only when private capital forced the issue. It is quite evident that there are fundamental contradictions in the economic philosophy of the President, some principles bearing a relation to Fascism at times and to socialism at others. Verna Carleton Millan was probably correct when she said: "His [Cárdenas'] conduct was of ten marked by exasperating inconsistencies, contradictions that are inevitable, indeed, in any leader whose ideological position docs not rest upon a firm, solid theoretical basis." ${ }^{\prime: s}$

\footnotetext{
${ }_{13 \pi}$ From a speech by Cárdenas, quoted in Townsend, Láaro Cárdenas, p. 346.

1:39 Millan, Mexico Rebom, p. 79.
} 
As to the political philosophy, while the Constitution does not provide for just one official party, in practice the official government party (in the Cárdenas era the P.N.R. and the P. R. M.) was able to discriminate effectively against any opposition. Perhaps this characteristic has something in common with both the Russian system and the Fascism of Italy and Germany. The philosophy of the administration was not militaristic or expansionist, but was rather for a movement towards civilian control of national life, something quite new to Latin America, and for non-aggression and universal peace. In this regard the thought could probably correctly be considered in harmony with Fabian socialist doctrine.

It is significant, I believe, that not only was the general politicoeconomic thought of Cárdenas and his administrative officers somewhat contradictory and ever-changing, but that also the philosophy of Lombardo Toledano, the legitimate spokesman for the organized labor movement during the period, was most variable, going from the position that workers were organized into trade unions for the sole purpose of opposing the government and establishing a dictatorship of the proletariat, with the complete socialization of property, to the position that the goal of Mexican workers was nothing more than to cooperate with a progressive administration to achieve the passage and enforcement of legislation favorable to the working class, as well as to all other sectors of the society. He claimed that Mexican workers were not capable of and did not want a government of themselves exclusively. It would seem, however, that Lombardo's variability could better be explained in terms of changing tactics to meet what he saw as a world-wide Fascist threat than as a change in basic philosophy. There is no evidence that this labor leader held any long-term philosophy other than " orthodox" Marxism during the period.

It is probable that one of the most consistent theorists of the Cárdenas administration was Ramón Beteta, who was convinced that the evils of capitalism were due merely to the legal question of who owned the productive machinery. He desired the intervention of a government with working-class interests for the end of establishing a society without classes "which in our day is the condition nearest to the ideal in the economic relations of man."

Perhaps the most unique development in the economic philosophy of the time was the acceptance of the fact that since the class struggle was inherent in a capitalist society, the interests of the opposing classes could be harmonized by intervention of the state, accepting a principle 
argued by Madison in the Federalist. And under Cárdenas the state was to intervene on the side of the weaker class, the laborers, on the theory that to treat two unequal parties equally accomplished neither justice nor equity. One cannot but wonder if Cárdenas would have suggested state intervention on behalf of the capitalist class had the working class become stronger, and thus have attempted to achieve an equilibrium position, accommodating all classes which exist in a privateownership society. (Apparently the Latins are as fascinated with "equilibrium economics" as are the Anglo-Saxons!) The theory of state interventionism, in a system of predominantly privately-owned facilities of production, in order to obtain more favorable conditions for workers is indeed quite similar to that adopted in all industrial nations of the West in the last few decades. Perhaps it can be called neither fascist, socialist, nor communist, yet contains aspects of all three, and may even be the "new synthesis."

The main principle of the Cárdenas labor theory was that the function of the modern state was primarily that of arbiter in the conflicts between capital and labor, lending its support to the working class. It would seem that this philosophy of labor-employer relationships presupposes the existence of a private employer class and that, therefore, the President did not have in mind a socialist society in the traditional sense. In Mexico under Cárdenas the conciliation and arbitration by government boards, while advocated by the administration, was not compulsory; and in case either side refused to submit the question to arbitration the conflict merely continued until one side or the other gave in. It should be remembered, however, that if the strike accompanying a dispute had been declared legal by the government board, the employer was responsible for the wages of the workers for the time lost while on strike. Therefore, so long as the boards were favorably inclined toward labor, the employer had little choice but to settle. The alternative was to close down and turn the establishment over to the government to be run for the laborers. If either party pleaded that a question of "economic order" was involved in the dispute, however, the board, after hearing the decision of a commission of experts, could render a decision fundamentally changing the terms of employment.

The inclusion of an elaborate article in the Constitution of the nation outlining minimum requirements for the protection of human labor, reflected the denial of the individualistic philosophy of laissez-faire and acceptance of the doctrine that the state should assume the responsibility for protecting workers from the vagaries of the "free market" economy. The Federal Labor Law of 1931 indicated the general belief 
in state intervention to protect workers, as set forth in the Constitution, and the further theory that both workers and employers should organize into associations and bargain collectively, preserving the right of peaceful strike, with the state as the mediator in conflicts between capital and labor, thus avoiding compulsory arbitration in principle, although having it in fact.

From the more specific observations, let us go to the more general. Millan saw the same apparent contradiction, or inconsistency, at which we have been hinting when she wrote:

This contradiction, of course, has always been the greatest flaw in every plan of the Mexican government; on the one side, the government approves "socialist" education, cooperative farming and other measures that if carried out fully must inevitably effect a complete transformation of the entire social system; but on the other hand it protects private property, is only opposed, and then relatively so, to foreign capital, but not to capitalism as an economic system. ${ }^{139}$

Insofar as I can judge, however, the evidence does not support the contention in the last line of the above quotation, since the statements and writings of every authority examined in this study definitely oppose capitalism as an economic system. It would appear, however, that the remainder of Millan's analysis is supported by the evidence available.

Bahamonde, in analyzing the philosophy of the Mexican reform movement, concluded that:

An objective analysis of the Mexican problems will show that Mexico does not imitate anybody in her work for the national well-being. Her doctrine, which is found fundamentally in the Constitution, is going little by little towards a particular brand of socialism, adjusted to the social needs of the people, which, it is clear, have a completely domestic and local aspect, absolutely different from all other countries. ${ }^{140}$ (Italics mine.)

He felt that the approach did resemble somewhat Italian Fascism in that Mexico respected private property, but imposed upon it determined limitations, especially on mineral and agricultural property, and he wanted the state to mediate between labor and capital. ${ }^{141}$ But he maintained that neither Fascism nor Communism nor classical liberalism adequately described the system, and thought that the solution which Mexico sought was distinct, searching for individual liberty, respect

${ }^{139}$ Millan, Mexico Reborn, p. 73.

140 Bahamonde, México Es Así, p. 65.

141 lbid., pp. 65, 70. 
for property and private initiative, harmonized with national necessities and the common well-being. He held that the program of the actual Mexican society was that of a country governed by democratic laws, inspired by socialist principles, which realized that human inequality existed and that the government ought to ameliorate its effects. Bahamonde claimed that Mexico had taken the doctrines of liberalism, socialism, syndicalism, and Communism, and recognized in them all some indisputable realities, proportions of which contributed to progress. ${ }^{142}$ Plenn, another authority on Mexican culture, felt that:

Cardenism is not Communism, nor Nazism, nor Fascism, nor "pure" democracy. Yet it has certain aspects of all four, with the modifications of its own traditions and environment.

Fully sixty-five per cent of Mexican industry and business is conducted on the same private-property capitalist basis as in the United States. It is true that there is a tendency toward the collectivism of an underdeveloped economy, with a strong feudal background. . . .

In practice, despite the abundant use of very radical slogans and symbols, the Mexican Socialist school is closer to Humanism and Rationalism; stresses the idea of cause and effect, science against mysticism and fatalism, faith in the human power to achieve; something resembling Poor Richard's maxim that God helps those who help themselves. ${ }^{148}$

"Cárdenas admired above all the social democracies of Scandanavia. But he studied the needs of his people in relation to their temperaments and potentialities and Mexico's resources and mores, and he used common sense as well as humanitarian principles to motivate his reforms." ${ }^{144}$

All of the authorities noted above seem to be correct in holding that the general aim of the Cárdenas administration was to improve the position and influence of the working masses, particularly the Indian, through state intervention of one sort or another on their behalf as circumstances demanded. Although it was announced that this goal was to be achieved through progressive "socialization" of the means of production, it must be remembered that what was meant by "socialization" varied from nationalization, to cooperative ownership, to private ownership with government regulation in favor of the working class.

The labor theory which was actually evolved during the Cárdenas administration was one of having a unified, organized labor monement,

142 lbid., p. 71.

${ }_{143}$ Plenn, Mexico Marches, pp. 360-361.

${ }^{\mathbf{4} 4}$ Strode, Timeless Mexico, p. 311. 
under the influence of the state, joined with other sectors of the society into a popular front, with the government acting as arbiter between capital and labor, favoring the working class. Other gains for labor were to be achieved through favorable legislation and limitations upon the use of private property.

One can only conclude that upon occasions the theory of the Revolution under Cárdenas bore a close relationship to "orthodox" socialism, while upon other occasions it was a type of state interventionism, a sort of "third position" under which the workers were to be the dominant influence in a popular front government, utilizing this position to regulate private capital in their favor. In short, it seems apparent that the Cárdenas administration accepted the Marxian analysis of the economic crisis of capitalism, but often sought to apply a native remedy, shaped largely by outside forces, which cannot properly be classified under any of the existing "isms." This fundamental lack of theoretical unity, or consistency, these "inner-contradictions" which have been well pointed up by Eyler Simpson, ${ }^{145}$ may go far in explaining the different approaches to reform in the national economic policy of the Cárdenas administration. Strangely enough the phrase "workeroriented-benevolent-Fascism " seems to be contradictory enough to describe adequately the socio-economic theory of the period. In the short view at least, possibly disappointing to Marxists, Fascists, and classical liberals alike, the labor theory of the Cárdenas era simply called for an alliance between government and labor, aimed to lead to the betterment of labor's position within a government-regulated, private-ownership economy.

Arlington State College,

Joe C. Ashby Arlington, Texas

${ }^{145}$ Eyler N. Simpson, The Ejido: Mexico's Way Out (Chapel Hill, 1937), Chapters 18 and 19. 